\title{
Selection of anthracnose resistant common beans using detached leaves in partially controlled environment ${ }^{1}$
}

\author{
Alisson Campos Pereira ${ }^{2}$, Ramon Gonçalves de Paula ${ }^{3}$, Trazilbo José de Paula Júnior ${ }^{4}$, Leonardo Corrêa da Silva , \\ José Eustáquio de Souza Carneiro ${ }^{6}$ Pedro Crescêncio Souza Carneiro ${ }^{7}$
}

http://dx.doi.org/10.1590/0034-737X201461040010

\begin{abstract}
The objectives of this study were to evaluate the possibility of selecting anthracnose resistant common bean plants using detached primary leaves in partially controlled environment of a greenhouse and identify differences in the reaction of genotypes to anthracnose. The common bean cultivars Ouro Negro, OuroVermelho, ManteigãoFosco 11, Rudá, Rudá-R, VP8, BRSMG Madrepérola, Pérola, MeiaNoite and BRSMG Talismãwere characterizedfor resistance to the races 65, 81 and 453 of Colletotrichum lindemuthianum and the method of detached primary leaves was compared to the method with the traditional inoculation of plants at the phenological stage V2. The lines Rudá, Rudá$\mathrm{R}$ and Pérola were inoculated with the races 65 and 453 of $C$. lindemuthianum, aiming to assess the rate of coincidence of anthracnose severity by both inoculation methods. In general, the two methods presented similar results for the reaction of the cultivars. The use of detached primary leaves of common bean plants in the partially controlled environment was feasible for selection of plants resistant to anthracnose and has the advantages of low-needed infrastructure and reduction of resources, space and time.
\end{abstract}

Key words: Colletotrichum lindemuthianum, inoculation methods, genetic resistance.

\section{RESUMO}

\section{Seleção de plantas de feijoeiro resistentes à antracnose, utilizando folhas destacadas, em ambiente parcialmente controlado}

O objetivo deste trabalho foi verificar a possibilidade de se efetuar seleção de plantas de feijoeiro resistentes à antracnose, utilizando-se folhas primárias destacadas em ambiente parcialmente controlado, em casa de vegetação, e detectar possíveis diferenças na reação de genótipos de feijoeiro à antracnose. Para isso, as linhagens de feijoeiro Ouro Negro, Ouro Vermelho, Manteigão Fosco 11, Rudá, Rudá-R, VP8, BRSMG Madrepérola, Pérola, Meia Noite e BRSMG Talismã foram caracterizadas quanto à reação às raças 65, 81 e 453 de Colletotrichum lindemuthianum, comparando-se essa metodologia com a tradicionalmente utilizada, com inoculação de plantas no estádio fenológico V2. Posteriormente, as linhagens Rudá-R, Rudá e Pérola foram inoculadas com as raças 65 e 453 de C. lindemuthianum, com o objetivo de avaliar o índice de coincidência da severidade da antracnose pelas duas metodologias de inoculação. Em geral, as duas metodologias proporcionaram resultados semelhantes quanto à reação apresentada pelos cultivares. A utilização de folhas primárias destacadas de feijoeiro em ambiente parcialmente controlado mostrou-se viável para a seleção, quanto à resistência à antracnose, com as vantagens da menor infraestrutura necessária e da redução de recursos, espaço e tempo.

Palavras-chave: Colletotrichum lindemuthianum, metodologias de inoculação, resistência genética.

\footnotetext{
Received: 02/04/2013; Approved: 23/10/2013

${ }^{1}$ Financed by Capes, CNPq and Fapemig.

${ }^{2}$ Agronomist, MSc. Universidade Federal de Viçosa, Campus Viçosa, Avenida Peter Henry Rolfs, s/n, 36570-000, Viçosa, Minas Gerais, Brasil. alisson.pereira@ ufv.br (corresponding author).

${ }^{3}$ Undergardtuate in Agronomy. Universidade Federal de Viçosa, Campus Viçosa, Avenida Peter Henry Rolfs, s/n, 36570-000, Viçosa, Minas Gerais, Brasil. ramon.goncalves@ufv.br ${ }^{4}$ Agronomist, Doctor. EPAMIG, Vila Gianetti, 47, 36570-000, Viçosa, Minas Gerais, Brasil. trazilbo@epamig.br

${ }_{5}^{5}$ Agronomist. Universidade Federal de Viçosa, Campus Viçosa, Avenida Peter Henry Rolfs, s/n, 36570-000, Viçosa, Minas Gerais, Brasil. leonardo.correa@ufv.br ${ }^{6}$ Agronomist, Doctor. Departamento de Fitotecnia, Universidade Federal de Viçosa, Campus Viçosa, Avenida Peter Henry Rolfs, s/n, 36570-000, Viçosa, Minas Gerais, Brasil. jesc@ufv.br

${ }^{7}$ Agronomist, Doctor. Departamento de Biologia, Universidade Federal de Viçosa, Campus Viçosa, Avenida Peter Henry Rolfs, s/n, 36570-000, Viçosa, Minas Gerais, Brasil. carneiro@ufv.br
} 


\section{INTRODUCTION}

Anthracnose of common bean (Phaseolus vulgaris L.), caused by Colletotrichum lindemuthianum (Sacc. \& Magn.) Scrib, is a cosmopolitan disease that can cause up to $100 \%$ losses when susceptible cultivars are grown, environmental conditions are favorable and the disease stablishment occurs in the vegetative slage of plants (Pastor-Corrales \& Tu, 1989; Bianchini et al., 1997). The disease is favored by temperatures from 13 to $27^{\circ} \mathrm{C}$ and humidity above $90 \%$; but it is necessary that the conditions last for at least six hours (Bianchini et al., 1997; Paula Junior et al., 2006). When conidia germinate, germ tubes elongate and form appressoria that mechanically penetrate the cuticle and epidermis of the host plant (Pastor-Corrales \& $\mathrm{Tu}$, 1989). Symptoms of anthracnose can be observed all over the shoots. However, the typical symptoms of this disease are necrotic lesions of dark brown color on the veins of the underside of leaves and on stems (Bianchini et al., 1997). The use of resistant cultivars is one of the most viable alternatives for the control of anthracnose. However, they are not easy to obtain because of the large pathogen variability and the difficulty of working with different resistance genes at the same time using the traditional methods. Thus, the development and evaluation of new methodologies that will facilitate the selection of resistant plants, saving time and resources, are of great importance.

Some studies have demonstrated the feasibility of using detached leaves of common bean in approaches for improvement of disease resistance, especially rust (Rios et al., 2001; Souza et al., 2009). Studies using inoculation of detached leaves have also been performed for bean anthracnose (Tu, 1986; Bigirmana \& Höfte, 2001). However, these studies were performed in highly controlled environmental conditions and made no comparisons between the severities observed in detached leaves with those observed in the donor plants. Thus, possible interactions between the methodology of inoculation and genotype reaction were not detected. The objective of this work was to verify the possibility of selecting bean plants resistant to anthracnose, using primary leaves detached in partially controlled environment (greenhouse) and detect possible differences in the reaction of bean genotypes to anthracnose due to the methodology used.

\section{MATERIALS AND METHODS}

First, an experiment was conducted with different lines of common bean to compare the methodologies of seedling inoculation (phenological stage V2) and detached leaves (inoculation of excised primary leaves) in relation to anthracnose severity. The bean lines Ouro Negro, Ouro Vermelho, Manteigão Fosco 11, Rudá, Rudá-R, VP8,
BRSMG Madrepérola, Pérola, Meia Noite and BRSMG Talismã were characterized for resistance to races 65,81 and 453 of $C$. lindemuthianum. These races are among the most frequently found in Brazil and Minas Gerais and/ or are capable of infecting widely grown cultivars in the country (Paula Junior \& Zambolim, 2006; Silva et al., 2007). The experiment was arranged in a randomized complete block design, with each plot represented by eight plants and three replications.

Seeds from each line were pre-germinated on Germitest paper in a growth chamber at $25{ }^{\circ} \mathrm{C}$ and $100 \%$ relative humidity for $24 \mathrm{~h}$. After this time, the seedlings were transplanted into styrofoam trays with 128 cells each containing $30 \mathrm{~mL}$ of substrate (Tropstrato $\mathrm{HT}^{\odot}$, Vida Verde, Mogi Mirim, SP, Brazil) and kept in the greenhouse until inoculation. The evaporative cooling system of the greenhouse was set to keep the temperature at $24 \pm 4{ }^{\circ} \mathrm{C}$. Plants were watered once a day, with sufficient water to provide substrate saturation.

Inoculations were performed seven days after transplanting. Just before inoculation, one primary leaf of each donor plant was excised and its petiole inserted in trays of 128 cells, each containing $30 \mathrm{~mL}$ of substrate. Similar to the donor plants, the experiment was arranged in a randomized block design with three replications, each plot represented by eight primary leaves. The evaporative cooling system of the greenhouse was kept unchanged after the inoculations and relative humidity of $>95 \%$ was obtained by automatic micro-sprinkler irrigation set at 1 $\mathrm{min} /$ hour. These conditions were maintained until the evaluations.

For inoculum production, isolates of the races 65,81 and 453 of $C$. lindemuthianum were transferred into tubes containing sterilized bean pods partially submerged on potato dextrose agar (PDA) (Pio-Ribeiro \& Chaves, 1975). After the inoculation, the tubes were kept at $24 \pm 1^{\circ} \mathrm{C}$ in the dark for ten days. After this period, the pods were scraped using distilled water and the conidial suspension was adjusted to a concentration of $1.2 \times 10^{6}$ conidia $\mathrm{mL}^{-1}$. The conidial suspension was sprayed onto the adaxial side of the primary leaves, both on detached primary leaves and donor plants, using a manual sprayer (Pereira et al., 2013).

Ten days after inoculation, the anthracnose severity in donor plants and primary detached leaves of each race was assessed according to the modified nine-degree scale proposed by Pastor-Corrales (1992) (Figure 1). Scores from 1 to 3 were considered as resistance reaction (R) and equal or greater than 4 were considered susceptibility reaction $(\mathrm{S})$.

The second experiment was conducted to evaluate the coincidence index of anthracnose severity obtained with both inoculation methods, the detached primary 
leaves and bean plants at the V2 stage. In this experiment, the races 65 and 453 of $C$. lindemuthianum were inoculated onto donor plants and detached leaves of the genotypes Rudá-R, Rudá and Pérola. These genotypes were selected because of their reactions to races 65 and 453. The line Rudá - $\mathrm{R}$ is resistant to both races, while Rudá and Pérola are susceptible to both races (Melo et al., 2008). In this experiment, the detached primary leaves and their donor plants were identified, in order to compare their reaction one by one. The methods of inoculum preparation, inoculation and evaluation as well as the conditions under which the plants were kept were the same as previously described.

After the evaluations, the coincidence index between the response of the detached primary leaves and their respective donor plants was calculated. For the index calculation, the reactions of resistance and susceptibility were attributed to the donor plants and detached primary leaves based on the severity scores. Then, the percentage of donor plants that had the same reaction of the detached primary leaves was calculated.

\section{RESULTS AND DISCUSSION}

Regardless of the inoculation method, a significant effect $(\mathrm{P}<0.01)$ was found for the source of variation Lines (L) for the races 65, 81 and 453 of C. lindemuthianum, i.e., the lines behaved differently across the three races. The source of variation Lines x Inoculation Methods (L x IM) was significant at $1 \%$ probability for the races 65 and 453 of $C$. lindemuthianum, indicating that one or more lines showed different anthracnose severity, depending on the inoculation method (Table 1).

The results obtained with plants and detached primary leaves were, in general, similar. However, different results were found for Ouro Negro, when it was inoculated with the race 65 of $C$. lindemuthianum (Table 2). This result can be explained by the low intensity of anthracnose symptoms in the leaves of this line and that, in the plants inoculated in the traditional manner, the symptoms occurred mainly in the stems. The occurrence of anthracnose symptoms on stems of bean plants is relatively common in highly susceptible genotypes, which is the case of Ouro Negro to certain isolates of race 65 of $C$. lindemuthianum. For all other genotyperace combinations tested, the two methods gave similar results for the resistance/susceptibility reaction. Other authors also reported the possibility of selection of bean plants resistant to $C$. lindemuthianum using detached leaves. Tu (1986) and Bigirmana \& Höfte (2001) concluded that the use of detached primary leaves and detached trifoliate leaves proved to be an effective technique of selection. However, because these studies made no comparison between the results obtained by inoculation of detached leaves with those obtained in the donor plants, it was not possible to confirm the consistency of the methodology used.

For the race 453 of $C$. lindemuthianum, the cultivars Ouro Vermelho and Rudá showed, in some cases, higher mean anthracnose severity scores when inoculations were made on detached leaves, however, there were no differences in the classification of the cultivars as susceptible or resistant (Table 2). Differences between the two inoculation methods for susceptibility of bean genotypes to leaf pathogens were also observed by other authors: Souza et al. (2009) tested the resistance of common bean to Uromyces appendiculatus on detached leaves and found that rust symptoms were earlier and more aggressive in detached leaves than in inoculated plants. In this case, because $U$. appendiculatus is an obligate pathogen, possible differences between the methods of inoculation may be due to physiological factors involved in host-pathogen interaction.

In the second experiment, a coincidence index of $87.3 \%$ between the reactions of resistance and susceptibility of the two methods of inoculation was observed for the race 65 of $C$. lindemulthianum. The coincidence index for race 453 was $74.7 \%$. However, considering that during the selection for resistance to anthracnose usually only resistant plants are chosen, that is, plants with severity scores above 3 are discarded, the coincidence index
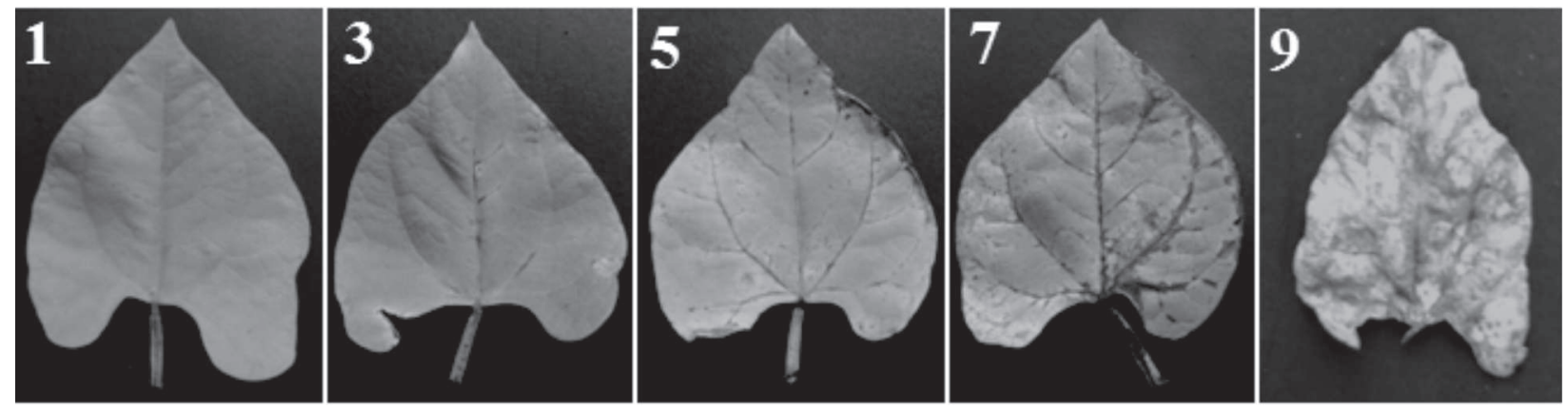

Figure 1. Diagrammatic scale of anthracnose severity in detached primary leaves of common bean based on the score scale modified from Pastor-Corrales (1992).

Rev. Ceres, Viçosa, v. 61, n.4, p. 518-522, jul/ago, 2014 
Table 1. Summary of analysis of variance of the severity of anthracnose symptoms in common bean lines using two methods of inoculation

\begin{tabular}{lcccc}
\hline \multirow{2}{*}{ VS } & DF & \multicolumn{3}{c}{ MS } \\
\cline { 3 - 4 } & & Race 65 & Race 81 & Race 453 \\
\hline Lines (L) & 9 & $72.3586^{* *}$ & $96.3980^{* *}$ & $61.3817^{* *}$ \\
Methods of inoculation (MI) & 1 & $6.3700^{* *}$ & $0.0866^{\text {ns }}$ & $3.0600^{* *}$ \\
L x MI & 9 & $5.9787^{* *}$ & $0.0560^{\text {ns }}$ & $1.5244^{* *}$ \\
Error & 40 & 0.0839 & 0.0496 & 0.2921 \\
\hline CV $(\%)$ & & 8.09 & 5.40 & 13.29 \\
\hline
\end{tabular}

Table 2. Mean anthracnose severity scores of common bean lines after inoculation with races 65,81 and 453 of Colletotrichum lindemuthianum, using the methodologies of plant inoculation (PI) and detached primary leaves (DPL)

\begin{tabular}{|c|c|c|c|c|c|c|}
\hline \multirow{2}{*}{ Lines } & \multicolumn{2}{|l|}{ Race 65} & \multicolumn{2}{|l|}{ Race 81} & \multicolumn{2}{|l|}{ Race 453} \\
\hline & $\mathbf{P I}^{1}$ & $\mathbf{D P L}^{2}$ & PI & DPL & PI & DPL \\
\hline Ouro Negro & $8.27(\mathrm{~S})$ & $1.96(\mathrm{R})$ & $1.00(\mathrm{R})$ & $1.00(\mathrm{R})$ & $1.00(\mathrm{R})$ & $1.00(\mathrm{R})$ \\
\hline Ouro Vermelho & $1.00(\mathrm{R})$ & $1.00(\mathrm{R})$ & $1.00(\mathrm{R})$ & $1.21(\mathrm{R})$ & $4.77(\mathrm{~S})$ & 7.24(S) \\
\hline Manteigão Fosco 11 & $1.00(\mathrm{R})$ & $1.00(\mathrm{R})$ & $8.68(\mathrm{~S})$ & $8.24(\mathrm{~S})$ & $1.00(\mathrm{R})$ & $1.00(\mathrm{R})$ \\
\hline Rudá & $9.00(\mathrm{~S})$ & $8.92(\mathrm{~S})$ & $9.00(\mathrm{~S})$ & $8.92(\mathrm{~S})$ & $7.00(\mathrm{~S})$ & $8.30(\mathrm{~S})$ \\
\hline Rudá-R & $1.00(\mathrm{R})$ & $1.00(\mathrm{R})$ & $1.00(\mathrm{R})$ & $1.00(\mathrm{R})$ & $1.00(\mathrm{R})$ & $1.00(\mathrm{R})$ \\
\hline VP8 & $8.89(\mathrm{~S})$ & $8.44(\mathrm{~S})$ & $8.90(\mathrm{~S})$ & $8.53(\mathrm{~S})$ & $8.93(\mathrm{~S})$ & $8.40(\mathrm{~S})$ \\
\hline BRSMG Madrepérola & $1.00(\mathrm{R})$ & $1.00(\mathrm{R})$ & $1.00(\mathrm{R})$ & $1.00(\mathrm{R})$ & $1.00(\mathrm{R})$ & $1.00(\mathrm{R})$ \\
\hline Pérola & $6.91(\mathrm{~S})$ & 7.11(S) & $9.00(\mathrm{~S})$ & $8.93(\mathrm{~S})$ & 7.61(S) & $6.83(\mathrm{~S})$ \\
\hline Meia Noite & $1.00(\mathrm{R})$ & $1.00(\mathrm{R})$ & $1.00(\mathrm{R})$ & $1.00(\mathrm{R})$ & $6.63(\mathrm{~S})$ & $8.11(\mathrm{~S})$ \\
\hline BRSMG Talismã & $1.00(\mathrm{R})$ & $1.00(\mathrm{R})$ & $1.00(\mathrm{R})$ & $1.00(\mathrm{R})$ & $5.46(\mathrm{~S})$ & $6.05(\mathrm{~S})$ \\
\hline
\end{tabular}

Data refer to the mean anthracnose severity based on the 1 to 9-degree scale proposed by Pastor-Corrales (1992). Genotypes with means above 3.0 were considered susceptible.

R: resistant; S: susceptible.

between the two methodologies would rise to 96 and $86.7 \%$ for the races 65 and 453 , respectively. This result confirms the efficiency of detached primary leaves in the selection of plants for anthracnose resistance. A similar result was reported by Souza et al. (2009), who compared the inoculation of $U$. appendiculatus on plants and detached leaves in a F2 population of common bean: the coincidence index was $97.6 \%$ for resistant plants and $92.9 \%$ for susceptible plants. Bigirmana \& Höfte (2001) inoculated $C$. lindemuthianum onto detached trifoliate leaves of common bean and reported selection accuracy of $100 \%$ when the inoculation was performed on a susceptible cultivar.

Tu (1986) and Souza et al. (2009) pointed out several advantages of using the methodology of detached leaves, including: the same plant can be characterized according to the reaction to different races of a particular pathogen or even to the reaction to different pathogens; the results are obtained and the plants are kept alive and can even produce seeds, which can be of interest in different types of study; plants with more than one gene for resistance to a particular pathogen can be identified. Furthermore, this technique prevents a possible interaction among races of the same pathogen or different pathogens and can reduce costs and working time.
Generally, studies involving inoculation of detached leaves have been conducted using climatized rooms or BOD chambers, as well as Petri dishes and, in some cases, the leaves have been grown on agar, sucrose solutions or other nutrient solutions, making the whole process difficult and very costly. In this work, we demonstrated the possibility of selecting resistant plants without losing efficiency in the greenhouse, since a partial control of humidity and temperature are provided. Thus, the number of genotypes that can be assessed considerably increases and the cost drops drastically.

\section{CONCLUSIONS}

In common bean breeding programs, the use of detached primary leaves was shown feasible to select for resistance to anthracnose. This technique can be used in partially controlled environment such as in a greenhouse. The use of detached primary leaves can be unreliable in very specific race-genotype combinations and that involve genotypes that have a predominance of symptoms on stems and stalks and highly aggressive races of $C$. lindemuthianum. 


\section{REFERENCES}

Bianchini A, Maringoni AC \& Carneiro BSMTG (1997) Doenças do feijoeiro (Phaseolus vulgaris L.). In: Kimati H, Amorim L, Bergamin Filho A, Camargo LEA \& Rezende JAM (Eds.) Manual de Fitopatologia. Doenças das plantas cultivadas. $3^{\mathrm{a}}$ ed. São Paulo, Agronômica Ceres. p.376-399.

Bigirmana J \& Höfte M (2001) Bean anthracnose: inoculation methods and influence of plant stage on resistance of Phaseolus vulgaris cultivars. Journal of Phytopathology, 149:403-408.

Melo CLP, Ragagnin VA, Arruda KMA, Barros EG, Carneiro PCS, Paula Júnior TJ, Moreira MA \& Carneiro JES (2008) Caracterização fenotípica e molecular de genitores de feijão tipo carioca quanto à resistência a patógenos. Pesquisa Agropecuária Brasileira, 43:495-504.

Pastor-Corrales MA (1992) Recomendaciones y acuerdos del primer taller de antracnosis en América Latina. In: PastorCorrales MA (Ed.) La antracnosis del frijol común, Phaseolus vulgaris, en América Latina. Cali, CIAT. p.240-250 (Documento de Trabajo, 113).

Pastor-Corrales MA \& Tu JC (1989) Anthracnose. In: Schwartz HF \& Pastor-Corrales MA (Eds.) Bean production problems in the tropics. $2^{\text {nd }}$ ed. Cali, CIAT. p.77-104.

Paula Júnior TJ, Lobo Júnior M, Sartorato A, Vieira RF, Carneiro JES \& Zambolim L (2006) Manejo integrado de doenças do feijoeiro em áreas irrigadas. Viçosa, EPAMIG-CTZM. 48p.
Paula Júnior TJ \& Zambolim L (2006) Doenças. In: Vieira C, Paula Júnior TJ \& Borém A (Eds.) Feijão. $2^{a}$ ed. Viçosa, Editora UFV. p.359-414.

Pereira AC, Celin EF, Rezende LLS, Carneiro VQ, Lehner MS, Paula Júnior TJ, Carneiro PCS \& Carneiro JES (2013) Alternative method for inoculation of Colletotrichum Lindemuthianun on common beans. Annual Report of the Bean Improvement Cooperative, 55:139-140.

Pio-Ribeiro G \& Chaves GM (1975) Raças fisiológicas de Colletotrichum lindemuthianum (Sacc. et Magn.) Scrib. que ocorrem em alguns municípios de Minas Gerais, Espírito Santo e Rio de Janeiro. Experientiae, 19:95-118.

Rios GP, Andrade EM \& Costa JLS (2001) Avaliação da resistência de cultivares e linhagens de feijoeiro comum a diferentes populações de Uromyces appendiculatus. Fitopatologia Brasileira, 26:128-133.

Silva KJD, Souza EA \& Ishikawa FH (2007) Characterization of Colletotrichum lindemuthianum isolates from the state of Minas Gerais, Brasil. Journal of Phytopathology, 155:241-247.

Souza TLPO, Ragagnin VA, Sanglard DA, Moreira MA \& Barros EG (2009) Teste de resistência ao Uromyces appendiculatus por meio da inoculação do patógeno em folhas destacadas do feijoeiro. Acta Scientiarum Agronomy, 31:197-201.

Tu JC (1986) A detached leaf technique for screening beans (Phaseolus vulgaris L.) in vitro against anthracnose Colletotrichum lindemuthianum. Canadian Journal of Plant Science, 66:805-809. 